\title{
Research on Water in Robert Frost' s Poem Spring Pools from the Perspective of Archetypal Criticism
}

\author{
Jia Li \\ Department of Arts and Sciences, Jilin Agricultural Science and Technology College, Jilin, 132101, \\ China \\ email: 260241901@qq.com
}

\begin{abstract}
Keywords: Robert Frost; Archetypal Criticism; Water; Spring Pools
\end{abstract}
\begin{abstract}
The thesis focuses on the study of archetypal criticism to explore the archetype of water employed in Robert Frost's poem Spring Pools. Archetypes can be tracked back to mythologies and rituals which root deeply in our unconsciousness. It can be aroused in certain circumstance and influences our thoughts. The archetype of water in Frost's poem Spring Pools comes to be equated with such things as life and nourishment. With the application of archetypal criticism in this poem, the author tries to interpret the metaphorical meaning of water in order to have a better understanding of literary works.
\end{abstract}

\section{Introduction}

Robert Lee Frost is a four-time Pulitzer Prize-winning American poet. Frost lives in modern society, while his poems pay more attention to the natural beauty. Most of his poems describe the beauty of nature and portray the life of local people. The poetic language is very simple and common, just like daily dialogue. He believes that poems should "begin in delight and ends in wisdom”. Readers may find wisdom, peace and harmony in his poems. The poems are expanded from the description of lyric landscapes to the pursuit of the meaning of life.

Archetypal criticism proves to be an appropriate approach of appreciating literature. We are born with the memories of these original archetypes. It makes great differences in our thinking though we are unaware of it. Archetypal criticism will provide a new approach to the study of Frost's poems. Water serves as an archetype constantly appear in the literature. Water, concerned in Frost's poems, symbolically means life and nourishment. First let's have a brief review of the development of archetypal criticism and then explain the water archetype in Frost's poem spring Pools.

\section{Archetype and Archetypal Criticism}

The term archetype can be traced back to the philosophy of Plato. In his well-known Idea Theory, the word "idea" is prototype or archetype. Archetypal ideas or patterns exist in a "world of forms". Plato is the first philosopher to clarify the concept of archetypal or ideal forms. The archetypal forms have been explored extensively by many scholars since 19th century.

Sir James George Frazer (1854-1941), a Scottish social anthropologist, is considered one of the founding fathers of modern anthropology. His masterpiece The Golden Bough is a comparative study of mythology and religion. Frazer collects and studies the materials about original inhabitants and primordial people, then elaborates the origins and functions on magic, ritual and mythology with abundant examples around the world. By comparing similarities and differences among magical and religious beliefs and cultures around the globe, anthropologists try to find the universal laws which control the evolution of human beings. In The Golden Bough, he proposes that all myths are symbolic interpretation of certain rituals. Frazer finds lots of prototypes and patterns recurring in various rituals and myths, including the dying god, human sacrifice, scapegoat and many other symbols. Besides the contribution to anthropology, The Golden Bough also impacts literature tremendously. It offers a new approach to interpret literary works from the perspective of myths and rituals.

Carl Gustav Jung (1865-1971), a Swiss psychiatrist and psychotherapist, is the founder 
of analytical psychology. The central concept of analytical psychology is the collective unconsciousness. Jung divides the unconsciousness into two parts: personal unconsciousness and collective unconsciousness. The materials in the personal unconsciousness are individual memories in the past. While the contents and images in the collective unconsciousness are not personal experiences. Beyond our awareness, it can be awakened under a certain environment and control our thoughts and behaviors instinctively. Human experiences are passed down from our ancestors in the old time and are shared with people of all time periods and different cultures. In Jungian psychology, archetypes are universally present in individual psyches. Human being's heritage must influence writers greatly when they are composing their works. The literary works are the reflections of the collective consciousness. Creating literary works is the process of recalling the past memory although writers have not realized. Both Frazer and Jung play important roles in the development of archetypal criticism.

It is Herman Northrop Frye (1912-1991), a Canadian literary critic and literary theorist, who borrows some ideas from cultural anthropology and psychology and then develops the literary theory of myth-archetypal criticism. In his book Anatomy of Criticism, myth-archetypal criticism focuses not only on the literary texts themselves, but studies them in anthropological and cultural way as well. Frye declares that archetype is a typical or recurring image which helps to unify our literary experience. Frye notices that the repetition of the certain image, theme, character and situation is not merely a coincidence, which must be dominated by some general rules. Individual literary work can't exist independently from literary tradition. The purpose of literary criticism is trying to associate the individual literary work with the entire literature. The earliest literary genres are originated from rituals and myths. Archetypes are frequently appeared in mythologies and then developed in literary works. Studying archetypes is the process of associating the individual to the general. Frye's archetypal theories provide a now approach to interpret literary work and his achievements have far-reaching impacts on literary criticism.

\section{Water symbolizes for life}

Water is necessary for life and interestingly, we are all made of water. The archetype of water has a universal meaning of birth and fertility. Symbolically, it is often viewed as the source of life itself with the evidence of various creation myths in which life comes from primordial waters. According to the mythologies around the global, the universe is born in a chaos where full of water and fume. The lives of all creatures also originate from this chaos water. So water symbolizes for life as recorded in various mythologies.

As the Yellow River is the cradle of Chinese culture, the Aegean Sea is the cradle of Greek civilization. Greek mythology is greatly influenced by Oceanic Civilization because Greece settles besides the east of Aegean Sea. The primordial people, for lack of knowledge, can't explain some natural phenomenon, so they need some supernatural power to protect them. The environment in prehistoric period is terrible and people have no ability to fight with natural disasters and the other wild animals. The pictures in ancient cave indicate that some kinds of animals with trees and water around are worshiped by people to keep them safe from the danger.

In Genesis, God created the world from deep sea. He let the waters be gathered together, and dry land appeared. So God called the dry land Earth, and the gathered waters He called the Sea. The Lord God built a garden in Eden for Adam and Eve to live in. God never caused it to rain, but a stream came from the earth, dividing into four branches, to water the whole ground. The trees and plants in the garden are thrifty and prosperous. In Exodus, God offered water for Hebrews to leave Egypt and survive in the wilderness journey. Otherwise they will die. Later God promised His people the "well-watered garden”. So Water also symbolizes the blessing from God.

The origin of life coming from water is equal to the female's ability of fertility. So water is inevitably associated with the female. In Chinese mythology, $\mathrm{Nu}$ Wa created human being and all the other creatures in a great water. All the Goddesses in mythology are created from an archetype of Earth Mother. According to anthropological discoveries, the sculptures left from ancient time show the general similar traits: large belly, strong legs, ample breasts and big buttocks. All these 
typical features imply the vigorous fertility. Earth Mother is worshiped for the achievement of giving birth to children. Larger population in one tribe means great prosperity in the future. More people could be more powerful in fighting against natural disasters and the other enemies. The Earth Mother worship could bless the tribe continuity. Ancient people depend on the nature extremely, especially the earth which is essential for growing everything. The advent of agricultural period asks for more labors to produce more foods. Fertility not only refers to give birth to children but also to produce more foods from the earth. Earth Mother with supernatural power could preserve offspring from dying of disaster, give birth to more children and bless rich harvest. Further, we hold opinion that water, mother and earth are correlated tightly with each other. All the creatures will wither and die without water. From former experiences people insist that all living things are in debt to the fostering of water.

\section{Archetypal study of water in Spring Pools}

Spring Pools is the first poem in Frost's West-Running Brook collection. The water in Spring Pools illustrates the archetype of motherhood. The poem opens with the beauty of early spring in New England. Pools in forests stay still to reflect the "total sky almost without defect". What the trees have done is a turning point in the poem. Trees dip up the water to guarantee their own splendor. "The trees that have it in their pent-up buds/To darken nature and be summer woods---". The poet suggests trees to "think twice before they use their powers / To blot out and drink up and sweep away". Because absorbing up the water is a warning sign of the end of summer. Greed will lead self-destruction when winter is coming

No one can deny the fact that water is a necessity to life and growth, so it usually appears as birth symbol. The water in pools sacrifices her for the blossom of buds in the tress. Water is the origin of all living things, providing nutrition for the growth of flowers and trees. It is said that the spring water in a cave or a holly well has a magic power. It could heal a wound and revive a life. Trees and flowers in the poem are the children of spring water because water serves for them and preserves them from withering away. The archetype of water containing all human experiences roots in everyone's unconsciousness though we don't realize. It can be recalled and plays an important role in our minds under certain circumstances. Water archetype relates this poem with tradition. With the universal meaning of life, fertility and fruitfulness, the powerful archetypal image will guide us to have a deeper understanding of the theme.

\section{Conclusion}

With probing into the water archetype, we shall never regard it quite so casually again. We may remind of much spiritual richness in mythology, ritual and literary works. Man's common experiences with water afford it much profound connotation. It has gone beyond the concept of a natural substance to an eternal category. The archetype of water in Frost's poem Spring Pools comes to symbolize for life. Interpreting Frost's poems from the angle of archetypal criticism is helpful in understanding the relationship between literature and culture. The activities of archetype are unconscious process, but we can consciously try our best to absorb psychological heritage that our ancestors left and apply it in the practice. Archetypal criticism enhances our literary appreciation and understanding. 


\section{Acknowledgement}

In this paper, the research was sponsored by the Youth Fund Project of Jilin Agricultural Science and Technology College (Project No. Ji Nong Yuan He Zi [2014] 103)

\section{References}

[1] Carl G. Jung. Psyche and Symbol. New Jersey: Princeton University Press, 1991.

[2] Carl G. Jung. Psychological Reflections. Columbia: Columbia University Press, 1980.

[3] Carl G. Jung. The Archetypes and the Collective Unconscious. Beijing: China Social Science Publishing House, 1999.

[4] James Frazer . The Golden Bough: A Study in Magic and Religion. New York: Macmillan, 1922.

[5] Northrop Frye. Anatomy of Criticism: Four Essays. Princeton: Princeton University Press, 1971.

[6] Northrop Frye. The Great Code: The Bible and Literature. London: Harcourt Brace Jovanovich Publishers, 1982. 